\begin{tabular}{ll}
\hline \hline MINING AND METALLURGY INSTITUTE BOR & ISSN: 2334-8836 \\
& UDK: 622 \\
\hline \hline
\end{tabular}

\title{
RECYCLING IN THE FUNCTION OF SAVINGS AND GREEN ECONOMY OF MINERAL RESOURCES
}

\begin{abstract}
Recycling means the separation of materials from waste and reusing the same. It involves the collection, separation, processing and manufacturing the new products from already used parts. This work will provide the basic concepts of recycling in the function of savings the mineral resources. Savings of mineral resources, in this way, present one of the goals of green economy and the green economy implies the widespread use of renewable energy sources with as less as possible emission or occurrence and production of harmful substances into the environment. Savings of metallic mineral resources are mostly achieved by recycling, and therefore the recycling is a priority for achievement the sustainable development.
\end{abstract}

Key words: recycling, savings, mineral resources, green economy

\section{INTRODUCTION}

Recycling is a term which describes the process "waste" converting into raw materials from which the new products are formed. As such, it is a part of an integrated waste management system, and it is on the third place in the hierarchy of waste management. System of management and recycling the various types of waste is not only the environmental issue, but also became a part of the economic and energy potential of a country. Recycling has the economic, environmental, but also the social importance because it affects the raising of environmental awareness, helping the prevention in environmental pollution, saving the natural resources, consuming less energy in waste processing, from energy that is consumed for obtaining the products from raw materials, and at the end, the amount of waste is reduced by recycling. The most widespread distribution of waste includes the two cate gories: the industrial waste, generated in the industrial processes, and municipal waste, generated in households. Besides the harmful effects of waste on the environment, it is also very important the secondary source of metals as well as the other products, obtained by recycling. Statistical indicators of recycling in the world are different, ranging from Japan, which recycles $80-90 \%$ of waste, across the EU, which recycles 30$40 \%$ of waste, to small Serbia. which has the present recycling of waste, only 6-8\%. Based on the above data, it can be concluded that Serbia is still far from establishing an environmentally safe and efficient management system with certain types of waste.

This especially refers to the municipal waste, considering that today in Serbia almost a half of the amount of generated waste from households ends on the illegal landfills, what is a constant source of soil,

*Faculty of Management, Zaječar, biljana.ilic@fmz.edu.rs 
air and water pollution. Therefore, it is necessary for Serbia to make more effort for achieving better waste management as well as more efforts to introduce the new technologies that would enable this management. In terms of recycling, and technologies related to recycling, there is the concept of green technologies. The concept of green technology, which is a part of the green economy concept, has shown a sudden growth in recent years. In general, the "green trends" in 2012 has resulted into reduction of waste, recycling and reusing of processed products. Trend of sustainable development is present in the world for a long time as the trend of sustainable economy, ecology, i.e. social development. At the global level, the green economy is seen as the economy in which the economic solutions and innovations allows the society to use efficiently the resources, improving the welfare of people by the inclusive way with preserving the natural systems that sustain the awareness and mankind (UNEP, United Nations Environment Program, 2010).

\section{WASTE CLASSIFICATION}

Waste characterization is the process of testing which determines the physicochemical, chemical and biological properties and composition of $t$ waste, i.e. determines whether the waste contains or does not contain one or more hazardous characteristics. Waste classification is the process of classifying the waste into one or more waste lists, which are regulated by separate regulations, and according to its origin, composition, and further purpose; (Waste Catalogue, 2010). The Act on Waste Management requires that the waste would be described in a way that allows the safe handling and waste management, as well as any change of ownership of waste would be accompanied by appropriate documentation that necessarily include the waste index number. The waste is classified according to the Waste Cata logue that is consistent with the European Waste Catalogue (European List of Waste/European Waste Catalogue). Within the Catalogue, the waste is systematized primarily according to the activities within which it is generated, but also according to the type of waste, materials or processes. The Waste Catalogue includes systematically more than 800 types of waste, divided into 20 groups, which are indicated by twodigit numbers and divided as follows:

1. Waste generated from exploration, exploration from mines or quarries and physical and chemical treatment of minerals;

2. Waste generated from agriculture, horticulture, forestry, hunting and fishing, food preparation and processing;

3. Waste generated from wood processing and production of paper, cardboard, pulp, panels and furniture;

4. Waste generated from leather, fur and textile industries;

5. Waste generated from petroleum refining, natural gas purification and pyrolytic treatment of coal;

6. Waste generated from inorganic chemical processing;

7. Waste generated from organic chemical processing;

8. Waste generated from manufacturing, supplying and use of coatings (paints, varnishes and vitreous enamels), adhesives, seals and printing inks);

9. Waste generated from photographic industry;

10. Waste generated from thermal processes;

11. Waste generated from chemical surface treatment and coating of metals and other materials; hydrometallurgy of ferrous metals;

12. Waste generated from shaping the physical and mechanical surface treatment of metals and plastics; 
13. Waste generated from oil and residues of liquid fuels (except edible oils);

14. Waste generated from organic substances used as solvents, coolants as well as propellant gases;

15. Waste generated from packaging;

16. Waste not otherwise specified in the Catalogue;

17. Construction waste and demolition waste (including soil from contaminated sites);

18. Waste from health care of people and animals from system-related research;

19. Waste from the waste treatment plants for waste water treatment, off-site production and water treatment intended for human consumption and water for industrial usage;

20. Municipal waste (household waste and similar commercial, industrial and institutional waste) including separately collecting fractions.

From the above mentioned categories of waste, the next following sub-groups are separated: plastic, metal, wood, organic waste, paper, electronics, rubber, glass and waste oil. Listed wastes represent the secondary raw material for the new products. Solid waste is important in the recycling of waste. The solid waste is municipal, industrial and commercial, packaging and construction waste. Industrial and commercial waste are the most desirable, also the most wanted type of waste in the market. Without this kind of waste, the operators of private sector cannot survive. Items and devices of metals that have lost their value in use, often end up on landfill, and so actively pollute the environment. This type of waste is the secondary raw material for metal obtaining, because the new products are obtained by collecting and returning into recycling and, at the same time, the primary resources are saved and thus extending the life of the primary reserves of raw materials. The environmental pollution is reduced by this way. For example, it is estimated that $15 \%$ is lost of the total amount of produced copper, while the remaining amount is built into items and objects that serve to reusing. It is similar to steel, which is illustrated by data that nearly $75 \%$ of is nowadays obtained by recycling. The fact that total amount of municipal waste in the world has reached a worryingly high level, indicates the urgent taking of actions that lead to the waste reduction.

It can be noted, that the amount of waste is directly related to the production volume, and also development of the country. Developed countries produce more waste, due to higher production, but, on the other hand, these countries lead in development of technologies for waste suppression. In these countries, municipal waste is treated in the plant for sorting. For example, in the EU, the total amount of municipal waste that is burnt is $33 \%$. After such treatment, the remainder of waste is quantitatively less, so it is easier to deposit it. Considering all presented facts regarding to the waste, hereinafter, the importance of including the external costs will be present, which are directly related to the exploitation of mineral resources. It will be further clarify the importance of recycling to reduce the costs of metal obtaining and its economic justification.

\section{IMPORTANCE OF INCLUDING THE EXTERNAL COSTS IN THE EXPLOITATION OF MINERAL RESOURCES}

Externalities are the effects of positive or negative character, arising from the certain activities, while at the same they are not the result of acting the price mechanism. The term "external effect" was first used by the theorist of welfare economics, AS Pigou (1912), who set the foundations for the 
standard theory of externalities. Starting from market failures, Pigou made a setting on necessity of state intervention, which should ensure that market prices reflect the full social cost. Viewed from a theoretical point of view, in order to avoid transmitting of external costs to the entire community, their internalization is necessary, or inclusion the pollution costs into the price of products that cause pollution (Ilic et al., 2013). In the economic theory and practice, there are two groups of measures for regulation the externalities (Stanic, 2012):

1. Command-control (standards or constraints), and

2. Market measures (taxes and transferable licenses).

It should be noted that the external positive effects may exist both in production and consumption, and that they can be positive and negative. Positive externalities are benefits to the third parties and they are not included in the price of product. In the case of external effects in consumption, a subject of brings benefits to any person by his consumption, in order that it happens without creating the additional costs for this second person. Hence, he is not ready to recognize them in the price of goods that he buys for consumption purposes.

On the other hand with the positive externalities in production, a manufacturer provides benefits to the third party with its activity, but not to the people whom he sales his goods, so he does not charge any fees from the third parties for this activity (IlicPopov, 2000). An example of positive externalities is education. Negative externalities mean the costs of legal entity or individual causes, i.e. imposed by the other members of society, who are not included in the product price. Due to the scale of the negative external effects of their larger and more farreaching consequences, this type of external effects is paid much more attention.
Sustainable management of mineral resources has indicated that the price of metal is one of the main instruments for achieving this sustainability. If the classical economic model of supply and demand is taken into consideration, it can be concluded that the same includes a supply and demand curve, which defines the marginal costs of labor and capital. However, metal production from primary mineral resources results into costs incurred by direct or indirect damage and pollution of natural environment, but which the manufacturer does not include that in his forms of costs. If those costs are omitted, it certainly will not be the real and fair view of the state of modern human activity and in the action that costs arise. Therefore, the classical model of supply and demand has to include externalities, or external costs, which are expressed in the monetary or financial value of environmental pollution. But, how the environmental damage has to be determined? This question is imposed due to a reason of impossible accurately determining the damages caused by the environmental pollution. If the relief or air quality is violated, it is difficult to estimate the amount of losses as compared to the potential benefits of these natural conditions. It is easier to estimate the amount of loss on degradation the certain area of soil, on the basis of lost potential profit from the yield of crops grown or could be grown on them. The costs incurred due to the health problems of population can be also easier monetary expressed and displayed. Viewed both from environmental and financial side, certainly that no damages to the environment are desirable. But these damages are real and really exist, except that some damages cannot be removed, while some can be remediated. If the environmental pollutions do not have any value and as such do not appear in the economic model of supply and demand, it might be practical and their market value is zero. No matter how hard it is to determine the values of these damages, in 
order to protect life, and therefore the survival of human society, the externalities must be taken into consideration of modern economic analysis. The function of costs, incurred by pollution of natural conditions and environment in the economic analysis model, growing in a proportion with the increase in production and, for the purposes of this study, it can be assumed that these costs are directly proportional to the production of metals (Magdalinović et al., 2011).

On a global scale, mining and metallurgy are the biggest polluters of the environment, with cumulative and far-reaching consequences for the environment and climate change. The most obvious and most direct consequences of pollution are manifested through the air pollution by harmful gases (sulfur, carbon and nitrogen), mineral dust particles and heavy metals (lead, arsenic, manganese, cadmium, mercury) which have the alarming adverse effects on human health. Considering that the modern industry, including the mining industry, mostly pollutes the environment, the above mentioned analy sis can be applied to any of its branch.

Figure 1 shows a simple way of introducing the external costs in the analysis of metal supply and demand. The costs of metal production, labor and capital can be seen on the graph. Market equilibrium $\mathbf{R}_{\mathbf{1}}$, determined by the intersection of supply and demand graph, is equivalent to Q1 and price $\mathbf{C}_{\mathbf{1}}$. If the estimated external costs (environmental damage) are involved into the production costs, a new higher graph of supply is obtained that represents the sum of production and external costs, and which can be called the social costs. In introduction the external costs, the balance point $\mathbf{R}_{\mathbf{1}}$ is moved to point $\mathbf{R}_{\mathbf{2}}$, which represents the social optimum. If the supply $\mathbf{Q}_{\mathbf{2}}$ is lower and $\mathbf{C}_{\mathbf{2}}$ price is higher, it is easier to achieve the social optimum. Such approach of introduction the costs in the analysis of supply and demand has a justified meaning. Namely, the costs really exist and they slow down the depletion of primary metal reserves in the new equilibrium (Magdalinović-Kalinović, 2010).

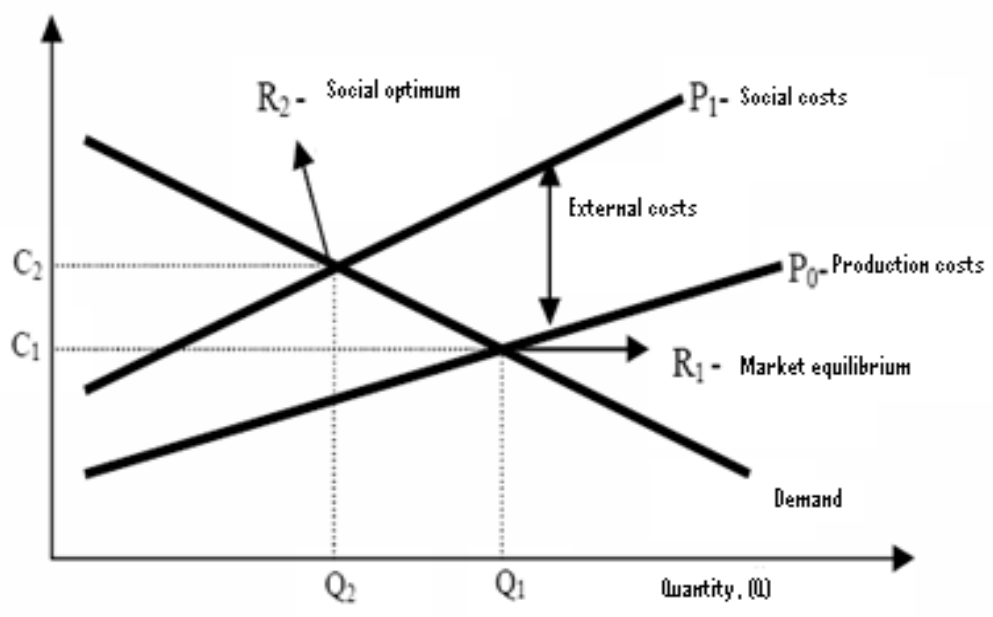

Figure 1 Model of supply and demand with external costs

The new equilibrium $\mathbf{R}_{\mathbf{2}}$ causes the price increase $\mathbf{C}_{2}$, while the sold quantity $\mathbf{Q}_{1}$ is reduced to $\mathbf{Q}_{2}$. The effect of eco nomic efficiency is good notwithstanding that the consumers would protest due to the price increase (the price is only the 
result of the real costs of production). If the sale is less, the production is also reduced and such production will reduce the environmental damage. On the other hand, the saving will be on the primary metal resources because their depletion will result into reduction. Such approach, i.e. the obtained new graphic, is approximate to the efficient equilibrium, i.e. the social optimum of metal production (from the primary reserves). Introducing the externalities into the classical model of supply and demand can be done in different ways, depending both on mineral resources and the way in which the same pollutes the environment. Tax on pollution presents one of the ways of introducing the external costs, which affect not only filling the state cash register, but also the awareness of producers on the natural environment, is really polluted. With higher tax on pollution, the supply of raw materials in the market is lower and higher raw material prices. This situation corresponds to the ecologists, because it is in favor of reduced environmental pollution, as the producers, in this manner, would be forced to produce less. However, the question may be freely asked about what the highest metal price to which the producers can go or that consumers can accept and pay. This is because the amount of pollution is associated with the technology that has to be changed and improved. If it is left the unchanged, the tax will only have a role in reduced supply and higher prices.

Recycling may be the answer to this and similar questions. If the metal price in the market achieves the upper critical level, the consumers will search for the new ways to substitute the same, i.e. they will turn to recycling. The metal is obtained from recycling process with less costs, and also lower pollution of the environment. From the standpoint of sustainable development, this is the most favorable option since it extends the life time of primary reserves for metal production at the same time reducing bad effects on the environment.
Therefore, it can be said that it is necessary to find the optimal level of pollution and harmonize the tax rates to that level. However, is the optimal pollution that which does not exist? The paradox is to use the word optimal when talking about pollution, considering the real awareness that optimal pollution is zero pollution. But, if it is taken into account that every, even the smallest production causes it, from an economic point of view, it is necessary that the production is zero, i.e. that does not exist. The society in any case has to decide what level of pollution is ready to accept. If the certain level of optimality is established, it is necessary to strive also the reduction of these "optimal" harmful effects. Such reduction can only be achieved applying the new technologies.

It can be stated that as long as there is production, there will be a level of pollution. To determine the optimal level, the economists have introduced into analysis a comparison the marginal costs of pollution $\mathbf{B C P}$, with the marginal costs of damage from pollution, which in this case will be marked with BCD. Figure 2 shows curves of these costs, and it can be concluded that the reduction of pollution is profitable while the costs of pollution control are less than benefits obtained from reduced damage.

The point $\mathbf{Q}_{\max }$, as maximum level of pollution, is the amount of pollution which has not been controlled. If, the pollution is reduced by taking the measures, the marginal costs of environmental damage will be decreased too. However, the less each pollution unit, the greater unit of control costs, that is, the marginal control costs are increased. In the convergence point of the graphic of the marginal pollution costs and marginal control costs, there is the point of optimum level of pollution, $\mathbf{Q}_{\mathrm{oz}}$. This point determines the amount of tax - $p$ on pollution (Figure 2) (Magdalinović-Kalinović, 2010). 


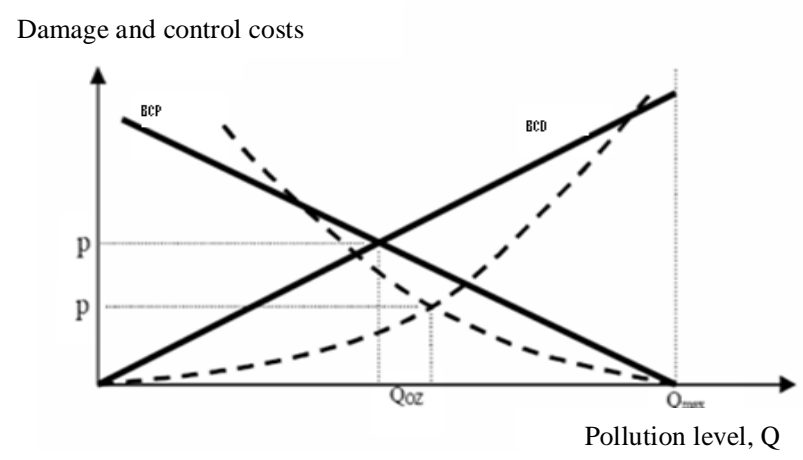

Figure 2 Marginal costs of damage and control

Although this analysis can be related to the certain obstacles in practice, such as some kinds of pollution expressed in monetary value, particularly when it is either cumulative pollution or esthetic damage of the relief, it is the only model to explain and comprehend the way on which the politics of pollution control affects producers to change the method of metal production and in that way to improve the awareness on the environment pollution. Recycling is the only efficient way to extend lifetime of the primary metal reserves. Figure 3 shows the profitability of recycling, represented by marginal production costs of metals from the primary sources and by recycling. The $x$ axis shows the portion of metal production by recycling, while the $y$ axis shows the marginal costs. As high as the portion of metals obtained from recycling, the marginal costs of metal production from recycling are higher, marked as TR. The costs of metal production by recycling first increase linearly, then along the graphic of exponential function. For the needs of work, it can be supposed that the marginal costs of metal production from the primary reserves, TPR, decline linearly. If the costs of the environmental damage are added to the costs of metal production from the primary reserves, the total costs of metal production from the primary reserves, UTPR, are obtained. The point of intersection the marginal costs and total costs of metal production, involving the sum of costs of metals obtained from the primary reserves and recycling costs, defines the optimum portion of metals obtained by recycling. Total costs are minimum; therefore, the portion of metal obtained by recycling is marked as optimum.

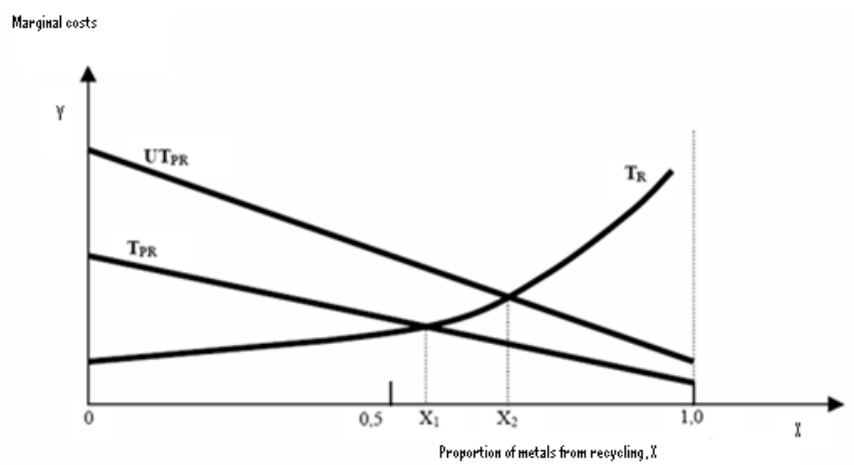

Figure 3 Marginal cost of metal production from the primary reserves and recycling 
However, including the external values into this analysis, it results into increase the optimum portion of metal production by recycling, from the point $\mathbf{X}_{\mathbf{1}}$ to the point $\mathbf{X}_{2}$. It is necessary to point out that beyond this point of the optimum portion of metals obtained by recycling $\left(\mathbf{X}_{2}\right)$, the costs of metals obtained by recycling increase rapidly. According to the graphic, it can be concluded that total recycling is both expensive and difficult; therefore, it is not justifiable. The amount of metal obtained by recycling is conditioned by development of a certain country. However, development is not the only condition but also estimated reserves, or natural wealth of metal reserves, as well as the economic profitability of obtaining the raw materials from the primary reserves. Since the West European countries have a lack of the primary raw materials for metal production, it is a good example to obtain considerable amounts of metals by recycling. South America, rich in copper, compared to the average values of the world, records two times less participation of cooper obtained by recycling than from the primary reserves. Tables 1 and 2 show data on the obtained copper by recycling, both per regions and per type of metal mostly obtained by recycling (Magdalinović et al., 2007).

Table 1 Share of recycled copper in total copper consumption in the world (\%)

\begin{tabular}{|l|l|l|l|l|l|l|l|}
\hline Region & $\mathbf{2 0 0 2}$ & $\mathbf{2 0 0 3}$ & $\mathbf{2 0 0 4}$ & $\mathbf{2 0 0 5}$ & $\mathbf{2 0 0 6}$ & $\mathbf{2 0 0 7}$ & $\mathbf{2 0 0 8}$ \\
\hline Asia & & & & & & & \\
\hline Europe & 30.9 & 30.0 & 31.7 & 33.1 & 37.7 & 34.2 & 34.0 \\
\hline North America & 44.4 & 41.6 & 41.2 & 41.5 & 41.0 & 41.3 & 42.7 \\
\hline Rest of the world & 32.4 & 31.5 & 30.5 & 31.1 & 33.2 & 34.1 & 33.0 \\
\hline All/ world & 16.3 & 14.0 & 14.6 & 16.6 & 17.1 & 18.8 & 16.3 \\
\hline
\end{tabular}

Source: International Copper Study Group, Copper Bulletin, 2010

Table 2 Metals obtained from recycling in the world, 2006

\begin{tabular}{|l|c|c|c|c|c|c|c|c|}
\hline Metal & Lead & Zinc & Copper & Nickel & Gold & Aluminum & Silver & Chrome \\
\hline $\begin{array}{l}\text { \% from } \\
\text { recycling }\end{array}$ & 72 & 26 & 37 & 35 & 43 & 49 & 16 & 25 \\
\hline
\end{tabular}

Source: http://home.clara.net/darvill/altenerg/wave.htm

\section{Index of Sustainability}

Sustainable development and its postulates on coordination of ecology, economics and society are closely related to the concept of green economy. Green economy is any economic activity involving profit, which, however, takes into account the environment, therefore, coordinating, at the same time, both factors. Strong sustainability includes the fact that the growth of economy must not be accomplished at the cost of exhausting non-renewable resources. The main indicators of sustainable development and the economy as well are the intergeneration righteousness and righteousness among the equals. The intergeneration righteousness means the amount of consumed natural resources that cannot be regenerated by human community that must not exceed the limit of utilization because this limit leads to the ecologic debt. Each ecologic debt is left to future generations to be paid. The achievements of the concept of sustainable development are observed by the certain indicators, based on 
modern ecologic postulates which identify the causal and consequential connections between the economic politics and politics of environmental protection and improvement. Realiable indicator warns to the problem before it becomes too serious, directing to the measures that are nece-ssary to be undertaken so that the problem can be solved. The indicators of sustai-nable development point to the weakness of causal and consequential connections between economy, the environment and society. Although they have some common properties, characteristic for their efficiency, they differ among themselves. Sustainable development defines the idea of the sustainability index in exploitation the mineral resources as the rate of production and consumption of metals, and it is determined in relation to the consumption of the primary reserves. Strategy of sustainable development means a continued, longterm reduction of consumption the primary reserves of metals with simultaneous increase of metal production by recycling. Hence, it leads to the rate of metal production by recycling and their consumption. The index of sustainable development, defined in this way, can range within the interval from 0 to 1. The higher index value, that is, closer to 1 , the better conditions for realization the sustainable development. Higher index of sustainability matches the positive contribution of the environment protection, since in the case of recycling, the amount of municipal waste is reduced and also the metal production from the primary, non-renewable, sources. The index of sustainable development can be 0 if obtaining of metals by recycling is 0 . The index can have the highest value, 1 , if the metal production by recycling is equal to its consumption. Regardless the fact that the index of sustainable development is defined in relation to the preservation of primary reserves, it points out the level of negative effect of metal production on the environment. The higher the index, the stronger sustainability, i.e., greater sa- vings of primary reserves and, therefore, better protection of the environment.

\section{CONCLUSION}

Taking into consideration the fact that population growth worldwide causes increase the amount of produced waste, the mankind is forced to pay the greatest possible attention to solving the problem of proper waste management. Rapid development of industrial production has caused increasingly greater consumption of the primary sources of raw materials for obtaining energy. Metals are consumed rapidly, and, if such rate is going to continue, the primary reserves will be consumed in a relatively short time. To bring down the consumption at the optimum level, and aiming to reduce the pollution of the environment, which has been considerably damaged by rapid industrialization, it is necessary to include the category of external costs in the conventionnal model of offer and demand of metals. These costs somehow express and evaluate the pollution of the environment. That is the way to establish the socially optimum balance on trade, resulting thus with higher price and less offer of metals from the primary reserves. Less production of metals from the primary reserves is positive from the point of view of sustainable development because it extends life time of the primary reserves and reduces the environmental pollution. Higher price of metals, as consequence of involvement the external costs, encourages producers to turn to higher metal production by recycling, the process from which they are obtained with significantly lower costs of production. Higher metal production by recycling leads to reduction of metal production from the primary reserves and in that way extends their existence. Recycling contributes to reduction of waste, resulting in reduction of environmental pollution. Reduction the environmental pollution is a positive, so-called "green"trend, involving the concept of "green economy". 


\section{REFERENCES}

[1] Ilić B., Stojanović D., Simeonović N. (2013): Trade of Transferable Permits in the Stock Market in the Function of Improvement the Environmental, Journal of Economics Niš, No. 4, pp. 172-185; (in Serbian)

[2] Ilić-Popov, G.: Environmental Taxes, Faculty of Law, University of Belgrade (2000), pp. 36; (in Serbian)

[3] Waste Catalogue Ministry of Environment and Spatial Planning, Agency for Environmental Protection of Serbia, Belgrade; (2010), (in Serbian)

[4] Magdalinović-Kalinović M.,: Magistarski rad, Technical Faculty Bor (2010); (in Serbian)

[5] Magdalinović-Kalinović M., Magdalinović N., Economic Model of Metal Recyclling, $5^{\text {th }}$ Symposium on Recycling Technology and Sustainable Development, Soko Banja (2010); pp. 106-117 (in Serbian)

[6] Magdalinović N., Magdalinović-Kalinović M., Mihajlović D.: An Addition to the Definition of the Sustainable Development Index in the Field of Metal Raw Materials, $3^{\text {rd }}$ International Conference on Sustainable Development Indicators in the Mining Industry, Milos Island, Greece (2007); pp. 97-107.

[7] Magdalinović N., Magdalinović- Kalinović M., Popović G.: Facts and Principles for Establishing the Management of Mineral Resources of Metals, 3-13. The First Symposium on Management the Mineral Resources with International Participation, Faculty of Management, Zaječar; (2011), pp. 3-15. (in Serbian)

[8] Stanić M., Public Measures and Instruments in the Environmental Policy, $10^{\text {th }}$ International Symposium Synergy, Bijeljina; (2012), pp. 413-420 (in Serbian)

[9] http://home.clara.net/darvill/altenerg/ wave.htm. Report of the U.S. Geological Society for 2007. 


\begin{tabular}{ll}
\hline \hline INSTITUT ZA RUDARSTVO I METALURGIJU BOR & ISSN: 2334-8836 \\
& UDK: 622 \\
\hline \hline
\end{tabular}

\title{
RECIKLAŽA U FUNKCIJI ŠTEDNJE I ODRŽIVE EKONOMIJE MINERALNIH SIROVINA
}

\begin{abstract}
Izvod
Pod reciklažom se podrazumeva izdvajanje materijala iz otpada i ponovno korišćenje istog. Ona podrazumeva sakupljanje, izdvajanje, preradu i izradu novih proizvoda od već korišćenih delova. $U$ radu će se dati osnovni pojmovi reciklaže u funkciji štednje mineralnih sirovina. Štednja mineralnih sirovina, na ovaj način predstavlja jedan od ciljeva zelene ekonomije, a zelena ekonomija podrazumeva široko korišćenje obnovljivih izvora energije uz što manju emisiju, odnosno pojavu i proizvodnju štetnih materija u prirodnu sredinu. Štednja metaličnih mineralnih resursa najviše se ostvaruje reciklažom, a samim tim predstavlja prioritet za ostvarenje održivog razvoja.
\end{abstract}

Ključne reči: reciklaža, štednja, mineralne sirovine, zelena ekonomija

\section{UVOD}

Reciklaža je pojam kojim se može opisati proces pretvaranja ,otpada“ u sirovine od kojih nastaju novi proizvodi. Kao takva, predstavlja deo integralnog sistema upravljanja otpadom, te se nalazi na trećem mestu u hijerariji upravljanja otpadom. Sistem upravljanja i recikliranja različitih vrsta otpada nije samo ekološko pitanje, već ujedno ulazi u sastav ekonomskog i energetskog potencijala jedne zemlje. Reciklaža ima ekonomski, ekološki, ali i društveni značaj jer utiče na podizanje ekološke svesti, pomaže u sprečavanju zegađenja prirodne sredine, štedi prirodne resurse, troši manje energije prilikom prerade otpada, od energije koja se utroši za dobijanje proizvoda od sirovina, na kraju, recikliranjem se smanjuje i količina otpada. Najrasprostranjenija podela, ubraja dve kategorije otpada $\mathrm{i}$ to industrijski, koji nastaje $\mathrm{u}$ industrijskim procesima $\mathrm{i}$ komunalni, koji nastaje u domaćinstvu.
Otpad je pored svoje štetnosti, koju ima na prirodnu sredinu, vrlo značajan sekundarni izvor metala, kao i drugih proizvoda koji se dobijaju reciklažom. Statistički pokazatelji reciklaže u svetu su različiti, te idu od Japana koji reciklira 80-90\% otpada, preko zemalja EU koja reciklira 30-40\% otpada, sve do male Srbije koja ima zastupljenu reciklažu otpada, svega 6-8\%. Na osnovu iznetih podataka može se zaključiti da je Srbija još uvek daleko od uspostavljanja ekološki bezbednog i efikasnog sistema upravljanja određenim vrstama otpada.

Ovo se posebno odnosi na komunalni otpad, obzirom da danas u Srbiji skoro upola količine prozvedenog otpada iz domaćinstva, završava na divljim deponijama, gde predstavljaju konstantni izvor zagađenja zemlje, vazduha i vode. Uputno bi bilo za Srbiju, da je potrebno da uloži više napora u postizanju boljeg upravljanju otpadom, te i više napora za uvođenje novih tehnologija

\footnotetext{
*Fakultet za menadžment, Zaječar, biljana.ilic@fmz.edu.rs
} 
koje bi to upravljanje i omogućile. U smislu recikliranja i tehnologija koje su vezane za reciklažu, nastao je i koncept zelenih tehnologija. Koncept zelena tehnologija, koji predstavlja deo koncepta zelene ekonomije, pokazao je nagli rast tokom proteklih godina. Uopšteno gledajući, ,zeleni trendovi“ u 2012. godini uticali su na smanjenje otpada, reciklažu i ponovno korišćenje prerađenih proizvoda. Trend održivog razvoja već duže vreme je prisutan u svetu, kao trend održive ekonomije, ekologije, odnosno društvenog razvoja. Na globalnom nivou, zelena ekonomija posmatra se kao ekonomija u kojoj ekonomska rešenja i inovacije omogućavaju društvu da efikasno koristi resurse, poboljšavajući dobrobit ljudi na inkluzivan način, uz očuvanje prirodnih sistema koji održavaju svet i čovečanstvo (UNEP, United Nations Enviroment Programme, 2010).

\section{KLASIFIKACIJA OTPADA}

Karakterizacija otpada predstavlja postupak ispitivanja kojim se utvrđuju fizičko - hemijske, hemijske i biološke osobine i sastav otpada, odnosno određuje se da li otpad sadrži ili ne sadrži jednu ili više opasnih karakteristika. Klasifikacija otpada predstavlja postupak svrstavanja otpada na jednu ili više lista otpada koje su utvrđene posebnim propisom, a prema njegovom poreklu, sastavu i daljoj nameni; (Katalog otpada, 2010) Zakon o upravljanju otpadom zahteva da otpad bude opisan na način koji omogućava sigurno rukovanje i upravljanje predmetnim otpadom, kao i da bilo koja promena vlasništva otpada bude propraćena odgovarajućom dokumentacijom koja obavezno uključuje indeksni broj otpada. Otpad se razvrstava prema Katalogu otpada koji je usklađen s Evropskim katalogom otpada (European List of Waste/European Waste Catalog). U okviru Kataloga, otpad je sistematizovan, prvenstveno, prema delatnostima u okviru kojih je generisan, ali i prema tipu otpada, materijalima ili procesima. U
Katalogu otpada je sistematizovano više od 800 vrsta otpada, podeljenih u 20 grupa, koje se označavaju dvocifrenim brojevima, te se dele na sledeći način:

1. Otpadi koji potiču od istraživanja, iskopavanja iz rudnika ili kamenoloma i fizičkog i hemijskog tretmana minerala

2. Otpadi iz poljoprvrede, holtikulture, avakulture, šumarstva, lova i ribolova, pripreme i prerade hrane

3. Otpadi od prerade drveta i proizvodnje papira, kartona, pulpe, panel i nameštaja

4. Otpadi iz kožne, krznarske i tekstilne industrije

5. Otpadi od rafinisanja nafte, prečišćavanja prirodnog gasa i pirolitičkog tretmana uglja

6. Otpadi od neorganske hemijske prerade

7. Otpadi od organske hemijske prerade

8. Otpadi od izrade, formulacije, pribavljanja i upotrebe premaza (boje, lakovi i staklene glazure), lepkovi, zaptivači i štamparska mastila

9. Otpadi iz fotografske industrije

10. Otpadi iz termičkih procesa

11. Otpadi od hemijskog tretmana površine i premazivanja metala i drugih materijala; hidrometalurgija obojenih metala

12. Otpadi od oblikovanja fizičke i mehaničke površinske obrade metala $i$ plastike

13. Otpadi od ulja i ostataka tečnih goriva (osim jestivih ulja)

14. Otpadi od organskih supstanci koje se koriste kao rastvarači, sredstva za hlađenje i kao pogonski gasovi

15. Otpadi od ambalaže

16. Otpadi koji nisu drugačije specificirani u katalogu

17. Građevisnki otpad i otpad od rušenja (uključujući i zemlju sa kontaminiranih lokacija) 
18. Otpadi od zdravstvene zaštite ljudi i životinja - iz sistema povezanog istraživnja

19. Otpadi iz objekata za obradu otpada, pogona za tretman otpadnih voda, dalje od lokacije proizvodnje i pripremu vode namenjenoj ljudskoj upotrebi i vode za industrijsku upotrebu

20. Opštinski otpadi (kućni otpad i slični komercijalni industrijski otpadi), uključujući odvojeno sakupljajuće frakcije

Iz nabrojanih kategorija otpada izdvajaju se sledeće podgrupe i to: plastika, metal, drvo, organski otpad, papir, elektronika, gume, staklo i otpadna ulja. Nabrojane vrste otpada, predstavljaju sekundarnu sirovinu za dobijanje novih proizvoda. Značajna uloga u recikliranju otpada pripada čvrstom otpadu. U čvrsti otpad spada komunalni, indistrijski i komercijalni, ambalažni i građevinski otpad. Industrijski i komercijalni otpad spadaju u najpoželjnije i najtraženije vrste otpada na tržištu. Bez ove vrste otpada ne mogu opstati operateri privatnog sektora. Predmeti i uređaji od metala koji su izgubili svoju upotrebnu vrednost, neretko završavaju na otpadu, te tako aktivno zagađuju životnu sredinu. Ova vrsta otpada predstavlja sekundarnu sirovinu za dobijanje metala, jer se sakupljanjem i vraćanjem u ponovnu preradu, dobijaju novi proizvodi, ujedno se štede primarni resursi, a samim tim i produžava vek primarnih rezervi sirovina. $\mathrm{Na}$ taj način se smanjuje zagađenje životne sredine. Primera radi, od ukupne količine proizvedenog bakra, procenjuje se da se izgubi $15 \%$, dok se preostala količina ugrađuje u stvari i predmete koje služe ponovnoj upotrebi. Slično je i sa čelikom, o čemu govori podatak da se danas skoro $75 \%$ čelika dobija recikliranjem. Činjenica da je ukupna količina komunalnog otpada u svetu dostigla zabrinjavajuće visok nivo, ukazuje da je urgentno preduzeti akcije koje vode smanjenju istog.
Može se konstatovati da je količina otpada u direktnoj vezi sa obimom proizvodnje i sa razvijenošću zemlje. Razvijenije zemlje više proizvode otpad, zbog veće proizvodnje, ali sa druge strane prednjače u razvoju tehnologije za suzbijanje otpada. U ovim zemljama komunalni otpad se tretira u postrojenjim za sortiranje. Primera radi, u zemljama EU ukupno količina komunalnog otpada koji se sagoreva iznosi 33\%. Nakon takvog tretmana, preostali deo otpada je količinski manji, te ga je lakše deponovati. Obzirom na sve iznete činjenice vezane za otpad, u daljem tekstu predstaviće se važnost uključivanja eksternih troškova, koji su u direktnoj vezi sa eksploatacijom mineralnih sirovina. To će dalje rasvetliti značaj reciklaže u smanjenju troškova za dobijanje metala i u njenoj ekonomskoj opravdanosti.

\section{NEOPHODNOST UKLJUČIVANJA EKSTERNIH TROŠKOVA U EKSPLOATACIJI MINERALNIH SIROVINA}

Eksternalije predstavljaju učinke, pozitivnog ili negativnog karaktera, koje proizilaze iz određene aktivnosti, a da pri tome nisu rezultat delovanja mehanizma cena. Termin „eksterni učinak“ prvi je upotrebio teoretičar ekonomije blagostanja A. S. Pigou (1912) koji je postavio osnove standardne teorije eksternalija. Polazeći od tržišnih nedostataka, Pigou je izneo postavku o neophodnosti državne intervencije koja bi trebala da obezbedi da tržišne cene odražavaju pun društveni trošak. Posmatrano sa teorijskog stanovišta, kako bi se izbeglo prenošenje eksternih troškova na celokupnu društvenu zajednicu, neophodna je njihova internalizacija, odnosno uključivanje troškova zagađenja u cenu proizvoda koje uzrokuju zagađenje (Ilić i drugi, 2013). U ekonomskoj teoriji i praksi postoje dve grupacije mera kojima se regulišu eksternalije: (Stanić, 2012) 
1) komandno-kontrolne (standardi ili ograničenja) i

2) tržišne mere (porezi i prenosive dozvole).

Potrebno je istaći da eksterni efekti mogu da postoje kako u proizvodnji, tako i u potrošnji, te da mogu biti pozitivni i negativani. Pozitivni eksterni efekti predstavljaju koristi za treća lica i nisu uključeni u cenu proizvoda. U slučaju eksternih efekata u potrošnji, jedan subjekat svojom potrošnjom donosi koristi nekom licu, s tim što se to dešava bez stvaranja dodatnih troškova za to drugo lice. Otuda, on nije spreman da ih prizna u ceni robe koju kupuje radi potrošnje.

S druge strane, kod pozitivnih eksternih efekata u proizvodnji, jedan proizvođač svojom aktivnošću pruža koristi nekom trećem licu, a ne onim licima kojima prodaje svoju robu, tako da za tu aktivnost ne naplaćuje nikakvu naknadu od trećih lica (Ilić Popov, 2000). Primer pozitivnih eksternih efekata je obrazovanje. Negativni eksterni efekti označavaju troškove koje pravno ili fizičko lice uzrokuje, tj. nameće drugim članovima društva, a koji nisu uključeni u cenu proizvoda. S obzirom da su razmere negativnih eksternih efekata veće i njihove posledice dalekosežnije, ovoj vrsti eksternih efekata se posvećuje mnogo veća pažnja.

Prilikom održivog upravljanja mineralnim resursima, proizilazi da je cena metala jedan od glavnih ekonomskih instrumenata za dostizanje te održivosti. Ukoliko se u razmatranje uzme klasični ekonomski model ponude i tražnje, može se konstatovati da isti uključuje krivu ponude i tražnje, koje su definisane graničnim troškovima rada i kapitala. Međutim, proizvodnjom metala iz primarnih sirovina, nastaju troškovi koji su nastali posrednim ili neposrednim oštećenjem, odnosno zagađenjem, prirodne ili životne sredine, a koje proizvođač ne uključuje u svoje obrasce troškova. Ukoliko se oni izostave, to svakako neće biti stvarno stanje i objektivna slika savremenog ljud- skog delovanja i troškova koji pri tom delovanju nastaju. S toga je u klasični model ponude i tražnje neophodno uključiti i eksternalije, odnosno eksterne troškove, koji predstavljaju monetarno ili finansijski izraženu vrednost zagađenja životne sredine. Ali, na koji način monetarno odrediti oštećenja životne sredine? Ovo pitanje se nameće iz razloga što se ne može tačno utvrditi koliko zaista iznose štete nastale od zagađenja sredine. Ukoliko se naruši reljef ili kvalitet vazduha, teško je proceniti koliko iznose gubici u odnosu na moguće koristi od ovih prirodnih uslova. Lakše je proceniti koliko iznosi gubitak od degradacije određene površine zemljišta, na osnovu izgubljene potencijalne dobiti od prinosa kultura koje se na njima gaje, ili bi se mogle gajiti. Troškovi nastali usled zdravstvenih problema stanovništva, mogu se takođe lakše monetarno izraziti i prikazati. Posmatrano kako sa ekološke, tako i sa finansijske strane, svakako da nikakva oštećenja životne sredine nisu poželjna. Ali su ta oštećenja realna i zaista postoje, sa tom razlikom što je neka nemoguće otkloniti, dok je pojedine moguće sanirati. Ukoliko se zagađenjima prirodne sredine ne dodeli nikava vrednost, te se kao takvi ne pojavljuju u ekonomskom modelu ponude i tražnje, onda bi praktično i njihova tržišna vrednost bila jednaka nuli. Bez obzira na to koliko je teško zaista odrediti vrednost pomenutih oštećenja, u cilju zaštite života, a samim tim i opstanka ljudskog društva, eksternailje se moraju uzeti u razmatranje savremene ekonomske analize. Funkcija troškova nastalih zagađenjem prirodnih uslova i sredine u ekonomskom modelu analize, proporcionlano raste sa porastom proizvodnje, te se za potrebe ovog rada može pretpostaviti da su ovi troškovi direktno proporcionalni proizvodnji metala (Magdalinović i drugi, 2011). U globalnim razmerama rudarstvo i metalurgija su najveći zagađivači životne sredine, sa kumulativnim i dalekosežnim posledicama po životnu sredinu i klimatske promene. 
Najvidljivije i najdirektnije posledice zagađenja manifestuju se preko zagađenja vazduha štetnim gasovima (sumpor, ugljenik i azot), mineralnom prašinom i česticama teških metala (olovo, arsen, mangan, kadmijum, živa) čije su štetne posledice po zdravlje stanovništva alarmantne. S obzirom da savremena industrija, u koju spada i rudarska industrija, najviše zagađuje prirodnu sredinu, pomenuta analiza se može primeniti na bilo koju njenu granu.

Slika 1 prikazuje jednostavan način uvođenja eksternih troškova $u$ analizu ponude i tražnje metala. Na grafiku se mogu videti troškovi proizvodnje metala, odnosno radne snage i kapitala. Tržišna ravnoteža $\mathbf{R}_{\mathbf{1}}$, koja je određene presekom grafika ponude i tražnje, odgovara količini metala Q1 i ceni $\mathbf{C}_{\mathbf{1}}$. Ukoliko se $\mathrm{u}$ troškove proizvodnje uključe i procenjeni eksterni troškovi (oštećenje životne sredine), dobija se novi, viši grafik ponude koji predstavlja zbir proizvodnih i eksternih troškova, a koji se mogu nazvati društveni troškovi. Prilikom uvođenja eksternih troškova pomera se tačka ravnoteže $\boldsymbol{R}_{\boldsymbol{I}}$ u tačku $\boldsymbol{R}_{\mathbf{2}}$, koja predstavlja društveni optimum. Ukoliko je manja ponuda $\boldsymbol{Q}_{2}$, a veća cena $\boldsymbol{C}_{2}$, tim pre je lakše ostvariti društveni optimum. Ovakav pristup uvođenja troškova u analizu ponude i tražnje ima svoj opravdani smisao. Naime, troškovi zaista postoje i u novoj ravnoteži usporavaju iscrpljivanje primarnih rezervi metala (Magdalinović-Kalinović, 2010).

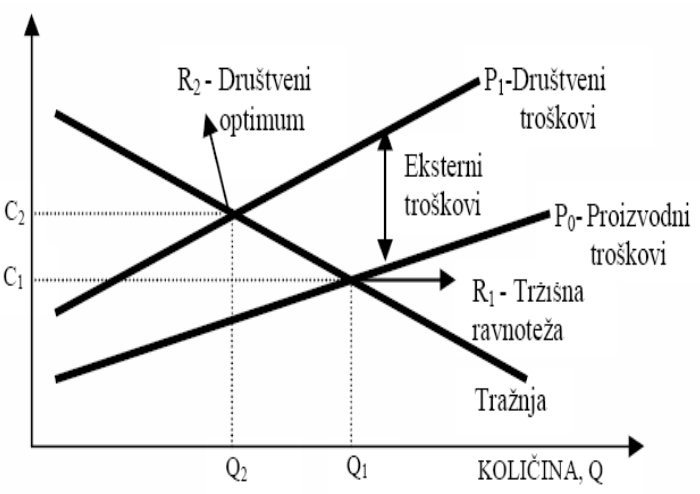

SI. 1. Model ponude i tražnje sa eksternim troškovima

Nova ravnoteža $\boldsymbol{R}_{\mathbf{2}}$ uslovljava rast cena $\boldsymbol{C}_{2}$, dok se prodata količina, sa $\mathbf{Q}_{\mathbf{1}}$ smanjuje na $\boldsymbol{Q}_{2}$. Efekat ekonomske efikasnosti je dobar bez obzira što bi potrošači negodovali zbog porasta cene (one su samo rezultat realnih troškova proizvodnje). Ukoliko je prodaja manja, smanjuje se i proizvodnja, a takva proizvodnja će smanjiti i oštećenje životne sredine. Sa druge strane, uštedeće se na primarnim izvorima metala, jer će i njihovo iscrpljivanje rezultirati smanjenjem. Ovakav pristup, odnosno dobijeni novi grafik, je približan efikasnoj ravnoteži, odnosno društvenom optimumu proizvodnje metala (iz primarnih rezervi). Uvođenje eksternalija u klasičan model ponude i tražnje može se uraditi na različite načine, u zavisnosti kako od mineralne sirovine, tako i od načina na koji ista zagađuje prirodnu sredinu. Porez na zagađenje predstavlja jedan od načina uvođenja eksternih troškova, koji utiče ne samo na popunjavanje državne kase, već i na svest proizvođača o tome koliko se prirodno okruženje zaista zagađuje. Što je poreza na zagađenje veća, to je i ponuda sirovina na tržišti manja, a cena sirovine viša. Ova situacija odgovara ekolozima, jer ide u prilog smanjenog zagađenja životne sredine, obzirom da proizvođači na ovaj način, budu naterani da proizvode manje. Međutim, 
može se slobodno postaviti pitanje o tome koja je najviša cena metala do koje proizvođači mogu ići, odnosno koju potrošači mogu i prihvataju da plate. Ovo iz razloga što je i količina zagađenja povezana sa tehnologijom, koja se mora menjati i usavršavati. Ukoliko ostaje nepromenjena, poreza će imati samo ulogu u smanjenoj ponudi i višoj ceni.

Odgovor na ovo i slična pitanja moguće je pronaći u reciklaži. Ukoliko cena metala na tržištu ostvari kritičnu gornju granicu, potrošači će tražiti nove načine za zamenu istog, odnosno okrenuće se reciklaži. Metal se iz reciklaže dobija uz niže troškove, a takođe i uz manje zagađenje životne sredine. Sa stanovišta održivog razvoja, ovo je svakako najpovoljnija situacija, jer produžava vek trajanja primarnih rezervi za dobijanje metala, ujedno smanjujući loše efekte po okolinu.

Dakle, može se reći da je potrebno pronaći nivo optimalnog zagađenja i uskladiti visinu poreza sa tim nivoom. Međutim, nije li optimalno zagađenje ono koje i ne postoji? Paradoks je upotrebiti reč optimalno kada se govori o zagađenju, obzirom na realnu svest da je optimalno zagađenje, nulto zagađenje. Ali, ukoliko se uzme u obzir da ga svaka, pa i najmanja proizvodnja izaziva, sa ekonomske tačke gledišta, potrebno je da i proizvodnja bude nulta, odnosno da ne postoji. Društvo se u svakom slučaju mora opredeliti koju količinu zagađenja je spremno da prihvati. Ukoliko se uspostavi određne nivo optimalnosti, neophodno je težiti smanjenju i tih ,optimalnih“ štetnih efekata. Takvo smanjenje je jedino moguće ostvariti primenom novih tehnologija.

Može se konstatovati da dokle god postoji proizvodnja, postojaće i nivo zagađenja. Da bi se utvrdio optimalni nivo, ekonomisti su uveli u analizu poređenje graničnih troškova zagađenja GTK, sa graničnim troškovima oštećenja od zagađenja, koje će u ovom slučaju biti obeleženi sa GTO. Na slici 2 su prikazane krive ovih tro-škova, te se može zaključiti da je smanjenje zagađenja isplativo sve dok su i troškovi od kontrole zagađenja manji od koristi dobijenih od smanjene štete.

Tačka Qmax, kao maksimalni nivo zagađenja, predstavlja količinu zagađenja bez ikakve kontrole. Ukoliko se preduzimanjem mera zagađenje smanji, smanjiće se i granični troškovi oštećenja životne sredine. Međutim, što je svaka jedinica zagađenja manja, to je svaka jedinica troška kontrole veća, odnosno granični troškovi kontrole se povećavaju. U preseku grafika graničnih troškova zagađenja i troškova kontrole, nalazi se tačka optimalnog nivoa zagađenja, tj. Qoz. Ova tačka određuje visinu poreza $p$ na zagađenje (sl. 2) (Magdalinović-Kalinović, 2010).

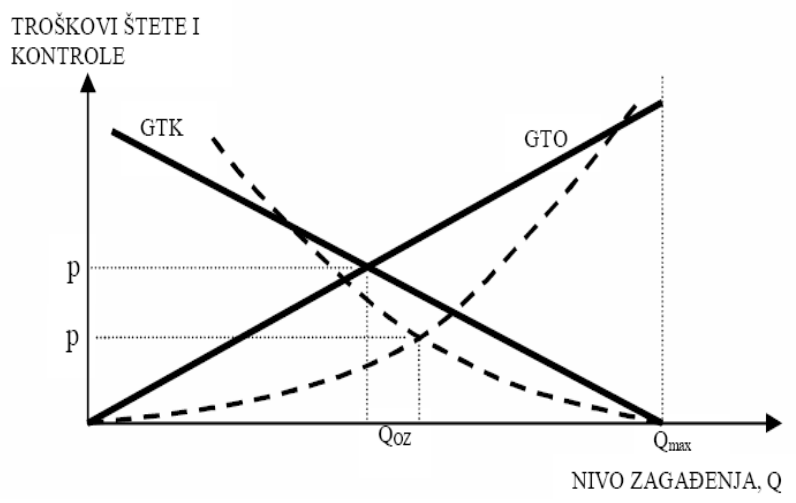

SI. 2. Granični troškovi štete i kontrole 
Iako je ova analiza u praksi vezana za određene poteškoće, u smislu monetarnog izražavanja određenih vrsta zagađenja, posebno kada je u pitanju kumulativno zagađenje ili estetsko oštećenje reljefa, ipak je to jedini model za pojašnjenje i shvatanje načina na koji politika kontrole zagađenja utiče na proizvođače, da promene način proizvodnje metala, te da podignu svest o zagađenju životne sredine. Reciklaža predstavlja efikasan način za produženje veka trajanja primarnih rezervi metala. Na slici 3 dat je prikaz ekonomske operavdanosti reciklaže, predstavljenu garničnim troškovima proizvodnje metala iz primarnih izvora $\mathrm{i}$ iz reciklaže. Na $x$ osi je dat udeo proizvodnje metala iz reciklaže, dok su na $y$ osi dati granični troškovi. Što je veći udeo matala iz raciklaže, to više rastu i granični troškovi proizvodnje metala iz reciklaže, koji su označeni sa TR. Troškovi proizvodnje metala iz reciklaže rastu pravolinijski, a potom po eksponencijalnom grafiku. $\mathrm{Za}$ potrebe rada, može se pretpostaviti da granični troškovi proizvodnje metala iz primarnih rezervi, označeni sa TPR opadaju pravolinijski. Ukoliko se na TPR, odnosno na troškove proizvodnje metala iz primarnih rezervi dodaju troškovi oštećenja životne sredine, dobijaju se ukupni društveni troškovi proizvodnje metala iz primarnih rezervi, označeni sa UTPR. Tačka preseka graničnih troškova i ukupnih troškova proizvodnje metala, koji predstavljaju sumu troškova metala iz primarnih rezervi i troškova iz reciklaže, definiše optimalni udeo metala iz reciklaže. Ukupni troškovi su minimalni, te se i udeo metala iz reciklaže označava kao optimalni.

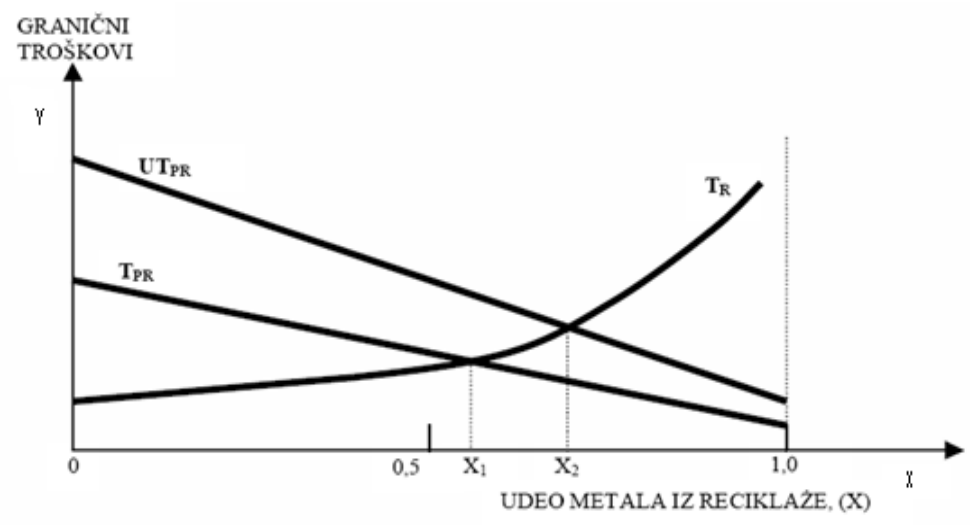

Sl. 3. Granični troškovi proizvodnje metala iz primarnih rezervi i reciklaže

Međutim, uključivanje eksternalija u ovu analizu, dovodi do povećanja optimalnog udela proizvodnje metala iz reciklaže i to sa $\mathbf{X}_{1}$ na $\mathbf{X}_{2}$. Potrebno je reći da iznad ove tačke optimalnog udela metala iz reciklaže $\left(\mathbf{X}_{2}\right)$, troškovi metala iz reciklaže naglo rastu. Sudeći po grafiku, može se zaključiti da je stoprocentno recikliranje skupo i teško, te samim tim i neopravdano. U zavisnosti od razvijenosti zemlje, zavisi i količina metala kopji se dobija iz reciklaže. Međutim, nije jedini uslov razvijenost, već i procenjene rezerve, odnosno prirodno bogatstvo metaličnim sirovinama, kao i ekonomska isplativost dobijanja tih sirovina iz primarnih rezervi. Primer za visoko učešće dobijanja metala iz reciklaže predstavlljaju zemlje zapadne Evrope, obzirom da iste oskudevaju 
u primarnim sirovinama za dobijanje metala. Bogata bakrom, Južna Amerika, beleži duplo manje učešća bakra iz reciklaže, u odnosu na svetski prosek. U tabeli 1 i 2 prikazani su podaci o dobijenom bakru iz reciklaže po regionima, ali i po vrsti metala koji se najviše dobijaju iz reciklaže (Magdalinović i drugi, 2007).

Tabela 1. Učešće recikliranog bakra u ukupnoj potrošnji bakra u svetu (izraženo \%)

\begin{tabular}{|l|c|c|c|c|c|c|c|}
\hline Region & $\mathbf{2 0 0 2}$ & $\mathbf{2 0 0 3}$ & $\mathbf{2 0 0 4}$ & $\mathbf{2 0 0 5}$ & $\mathbf{2 0 0 6}$ & $\mathbf{2 0 0 7}$ & $\mathbf{2 0 0 8}$ \\
\hline Azija & & & & & & & \\
\hline Evropa & 30,9 & 30,0 & 31,7 & 33,1 & 37,7 & 34,2 & 34,0 \\
\hline Sev. Amerika & 44,4 & 41,6 & 41,2 & 41,5 & 41,0 & 41,3 & 42,7 \\
\hline Ostatak sveta & 32,4 & 31,5 & 30,5 & 31,1 & 33,2 & 34,1 & 33,0 \\
\hline Ukupno svet & 16,3 & 14,0 & 14,6 & 16,6 & 17,1 & 18,8 & 16,3 \\
\hline
\end{tabular}

Izvor: International Copper Study Group, Copper Bulletion, 2010

Tabela 2. Udeo metala iz reciklaže u svetu, 2006.god

\begin{tabular}{|c|c|c|c|c|c|c|c|c|}
\hline Metal & Olovo & Cink & Bakar & Nikl & Zlato & Aluminijum & Srebro & Hrom \\
\hline$\%$ iz reciklaže & 72 & 26 & 37 & 35 & 43 & 49 & 16 & 25 \\
\hline
\end{tabular}

Izvor: http://home.clara.net/darvill/altenerg/wave.htm

\section{Indeks održivosti}

Održivi razvoj i njegovi postulati o usklađenosti ekologije, ekonomije i društva nalaze se u tesnoj vezi sa konceptom zelene ekonomije. Zelena ekonomija je svaka ekonomska aktivnost, koja podrazumeva dobit, ali koja usput vodi računa o prirodnom okruženju, te na taj način usklađuje ova dva.

Jaka održivost podrazmeva da ekonomski rast ne sme biti ostvaren po cenu iscrpljivanja neobnovljivih resursa. U glavne indikatore održivog razvoja, samim tim i ekonomije spadaju Intergeneracijska pravednost, kao i pravednost među jednakima. Intergeneracijska pravednost označav količinu korišćenih prirodnih resursa koji se ne mogu regenerisati, od strane ljudske zajednice, koja ne sme prekoračiti granicu iskorišćenja, jer to prekoračenje dovodi do ekološkog duga. Svaki ekološki dug biva ostavljen za plaćanje budućim generacijama, odnosno našoj deci. Dostignuća koncepta održivog razvoja se prate odgovarajućim indikatorima, zasnovanim na savremenim ekološkim zakonitostima, koji identifikuju uzročno posledične veze između ekonomske politike i politike zaštite i unapređenja životne sredine. Pouzdan indikator upozorava na problem pre nego što on postane suviše ozbiljan, te upućuje na mere koje je potrebno preduzeti kako bi se problem otklonio. Indikatori održivog razvoja ukazuju o slabosti uzročno posledičnih veza između privrede, životne sredine i društva. Oni se međusobno razlikuju, pored nekih zajedničkih osobina, karakterističnih za njihovu efikasnost. Održivi razvoj definiše pojam indeksa održivosti u eksploataciji mineralnih sirovina kao odnos između proizvodnje i potrošnje metala, a definisan je 
u odnosu na trošenje primarnih rezervi. Strategija održivog razvoja svodi se na kontinuirano, dugoročno smanjivanje potrošnje primarnih rezervi metala, uz istovremeno povećanje proizvodnje metala iz reciklaže. Samim tim dolazi se do odnosa proizvodnje metala iz reciklaže i njegove potrošnje. Indeks održivog razvoja, definisan na ovaj način se može kretati u intervalu od 0 do 1. Ukoliko je vrednost indeksa veća, odnosno bliža jedinici, to su i bolji uslovi za ostvarenje održivog razvoja. Veći indeks održivosti, odgovara pozitivnom doprinosu očuvanja prirodne sredine, jer se u datom slučaju, kada je u pitanju reciklaža količina komunalnog otpada smanjuje, kao i proizvodnja metala iz primarnih, neobnovljivih izvora. Indeks održivog razvoja može biti jednak nuli, ukoliko je i dobijanje metala iz reciklaže jednako nuli. A najveću vrednost, odnosno jedinicu, može imati ukoliko je proizvodnja metala iz reciklaže jednaka njegovoj potrošnji. Bez obzira što je indeks održivog razvoja definisan u odnosu na očuvanje primarnih rezervi, on ukazuje i na stepen negativnog uticaja proizvodnje metala na životnu sredinu. Što je ovaj indeks veći, to ukazuje na jaču održivost, odnosno na veću uštedu primarnih rezervi, a implicitno i na bolju zaštitu prirodne sredine.

\section{ZAKLJUČAK}

S obzirom na činjenično stanje, da se sa porastom broja stanovništva u Svetu, beleži i porast količine proizvedenog otpada, čovečanstvo je primorano da maksimalno posveti pažnju rešavanju problema pravilnog upravljanja otpadom. Nagli razvoj industrijske proizvodnje je doprineo i sve većoj potrošnji primarnih izvora energetskih sirovina. Ubrzano se troše i metali, a ukoliko se takva stopa nastavi, doći će se do potrošnje primarnih rezervi i to za relativno kratak vremenski period. Kako bi se potrošnja svela na neki optimalni nivo, a i u cilju smanjenja zagađenja životne sredine, koja je poprilično oštećena naglom industrijalizacijom, potre- bno je u klasičan model ponude i tražnje metala, uvesti i kategoriju eksternih troškova. Ovi troškovi na određeni način iskazuju i vrednuju zagađenje životne sredine. Time se uspostavlja društveno optimalna tržišna ravnoteža, koja rezultira višom cenom i manjom ponudom metala iz primarnih rezervi. Manja proizvodnja metala iz primarnih rezervi je pozitivno sa stanovišta održivog razvoja, jer produžava vek trajanja primarnih rezervi i smanjuje zagađenje životne sredine. Viša cena metala, kao posledica uvođenja eksternih troškova, podstiče proizvođače da se okrenu većoj proizvodnji metala iz reciklaže, odakle se on dobija uz značajno niže troškove proizvodnje. Veća proizvodnja metala iz reciklaže dovodi do smanjenja proizvodnje metala iz primarnih rezervi, te tako produžava njihov vek trajanja. Reciklaža doprinosi i smanjenju otpada, što rezultira smanjenju zagađenja životne sredine. Samo smanjenje životne sredine, predstavlja pozitivan, odnosno zeleni trend, u koji se ubraja i koncept zelene ekonomije.

\section{LITERATURA}

[1] Ilić B., Stojanović D., Simeonović N.: Trgovina prenosivim dozvolama na berzanskom tržištu u funkciji poboljšanja kvaliteta životne sredine, Časopis Ekonomika Niš, broj 4, 2013, str. 172-185.

[2] Ilić-Popov, G.: Ekološki porezi, Pravni fakultet Univerziteta Beograd, 2000, str. 36.

[3] Katalog otpada Ministarstvo životne sredine i prostorno planiranje, Agencija za zaštitu životne sredine Srbije, Beograd, 2010

[4] Magdalinović-Kalinović M.: Magistarski rad, Tehnički fakultet Bor, 2010.

[5] Magdalinović - Kalinović M., Magdalinović N., Ekonomski model reciklaže metala. 5. Simpozijum Reciklažne tehnologije i održivi razvoj, Soko Banja, 2010, str. 106-117. 
[6] Magdalinović N., Magdalinović-Kalinović M., Mihajlović D.: An Addition to the Definition of the Sustainable Development Index in the Field of Metal Raw Materials. $3^{\text {rd }}$ Inter. Conf. on Sustainable Development Indicators in the Min. Ind., Milos island, Greece, 2007, str. 97-107.

[7] Magdalinović N., Magdalinović - Kalinović M., Popović G.: Činjenice i principi na kojima treba zasnivati upravljanje mineralnim resursima metala
3-13. Prvi simpozijum o upravljanju prirodnim resursima, sa međunarodnim učešćem, Fakultet za menadžment, Zaječar, 2011, str. 3-15.

[8] Stanić M., Javne mjere i instrumenti u politici zaštite životne sredine, 10. Međunarodni naučni skup Sinergija, Bijeljina, 2012, str. 413-420.

[9] http://home.clara.net/darvill/altenerg/ wave.htm. Izveštaj američkog geološkog društva za 2007. god. 